\title{
Flood Susceptibility Mapping of Makera District and Environs in Kaduna South Local Government Area of Kaduna State-Nigeria
}

\author{
Ibrahim U. S. ${ }^{1}$, Youngu T. T. ${ }^{1}$, Swafiyudeen B. ${ }^{1, *}$, Abubakar A. Z. ${ }^{1}$, Zainabu A. \\ K. ${ }^{1}$, Usman I. A. ${ }^{2}$, Adamu S. ${ }^{1}$ and Abubakar A. M. ${ }^{3}$ \\ ${ }^{1}$ Department of Geomatics, Ahmadu Bello University Zaria, Nigeria \\ ${ }^{2}$ Waziri Umaru Federal Polytechnic, Birnin Kebbi, Nigeria \\ ${ }^{3}$ Department of Surveying and Geoinformatics, Nuhu Bamali Polytechnic, Zaria \\ Corresponding Author: *bswafiyudeen@gmail.com
}

https://doi.org/10.36263/nijest.2021.02.0287

\begin{abstract}
The increased flood incidences experienced all over the world due to climate change dynamics call for a concerted effort towards forestalling future hazards. This study thus, identified the areas that are susceptibility to floods in parts of the Makera district of the Kaduna South Local Government Area in Nigeria using geospatial techniques. Geographic Information System (GIS) was used to produce thematic layers of the factors contributing to flooding (elevation, slope, drainage density, rainfall, land use/land cover); and a multi-criteria evaluation particularly the "Analytical Hierarchical process" (AHP) was applied to determine the locations at risk. The various thematic layers were integrated into the weighted overlay tool in the ArcGIS 10.3 environment to generate the final susceptibility map. The overlay tool was also used to determine the elements at risk of flood in the study area. The results show that the areas that were highly susceptible to flood constituted about 39\% of the study area, while moderate and low vulnerable areas constituted about $26 \%$ and $35 \%$, respectively. The result of the multi-criteria analysis revealed that land uselland cover (0.601) was the factor that contributed the most to flooding in the study area based on the criteria weights followed by rainfall (0.470), drainage density (0.326), elevation (0.144), and slope (0.099), respectively. The study recommends that authorities concerned should ensure strict adherence to land use planning act, such that floodplains are avoided during development of any type.
\end{abstract}

Keywords: Flood, Geospatial technique, Multi-criteria analysis, Susceptibility

\subsection{Introduction}

The incredible amount of water (as far as waterway or fluvial flow is concerned) is basically brought about by the overwhelming precipitation that overflows into the streams which surpass the limits of the waterways, making water flow out over the land (Oxford Learner's Dictionary, 2020). Poor urban arrangement, urban populace development, poor ecological administration and the indiscriminate disposal of solid waste additionally influence flood occurrence. Flooding is apparently a climate related risk that occurs across the entire globe. It is a phenomenon which happens when flood water spreads or shrouds the land. Flood is one of the common natural risk desolating the scene of humanity throughout the years and at whatever point flood happen, they bring about the loss of properties, lives, destruction of farmlands and so on (Ojeh and Victor, 2014).

Flooding is turning into an increasingly frequent occurrence in Nigeria, most especially in urban areas where the impact can be overwhelming. Somewhere in the range of 2011 and 2012, there were cases of flooding in many parts of the country (Nkeki et al., 2013). The floods that inundated most parts of Kogi, Delta, Bayelsa, and Anambara states in 2012 are some typical examples. Territories around the River Niger were totally submerged by floods and in excess of 600,000 occupants were rendered homeless, farmlands and numerous lives lost (Nkeki et al., 2013). In the year 2012, Nigeria saw the 
most noteworthy flood disaster in 100 years, where more than 10 states of the federation were inundated. This occurrence was anticipated by the Nigerian Meteorological Agency (Okonkwo, 2013). According to specialists, submerge was brought about by abundant precipitation which brought about the over flooding of rivers Niger and Benue and their tributaries, from Taraba to Adamawa right toward the southern states of Nigeria.

At whatever point catastrophes of such incredible extents happen, endeavours are typically made to forestall future events where conceivable, or if nothing else limit the effects through different preventive projects and components (Vallecillo et al., 2020). Ever before now, and in comparable circumstances in Nigeria, manual techniques, for example, land survey, field studies, administration of questionnaires and interviews were the common methods of data acquisition and on which crucial decisions on such matters were made (Ikusemoran, 2000). The vast majority of these methods were found not adequate to give perpetual answers for such issues on the grounds that most on occasion, the disappointments of these choices originate from the issues related with the information on which such choices were based. Thus, there is the requirement for the utilization of computerized innovation, for example, remotely sensed information and Geographic Information System (GIS) methods for information and investigation. Hence, consequent choices that is liberated from human controls and which can be viewed as dependable and exposed to future update are required for flood risk evaluation in Nigeria.

Geospatial techniques have been successfully applied all over the world for flood monitoring, susceptibility, management and control. For instance, Haq et al. (2012) applied remote sensing and GIS to monitor and assess damages caused by flood in the Sindh province of Pakistan. MODIS Aqua and Terra images of the study area were acquired during the flood events and used as the main input to assess the damages with the help of GIS analysis tools. Pieter et al. (2010) applied GIS for flood risk management in Flanders: a region in Belgium where a risk-based technology was created to quantitatively assess flood risk based on hydrologic models, land use information and socio economic data. The method was said to have been implemented in a specifically designed GIS-based flood risk assessment called LATIS which was assessed to have the capability to perform risk analysis quickly and effectively. Nwilo et al. (2012) adopted remote sensing tools and Cellular Automated Evaluation Slope and River (CAESAR) to determine inundation level and assess the susceptibility of settlements in the floodplains of Adamawa State. The results showed that, an average of 134 settlements were prone to hazard. Elsewhere in Papua New Guinea, Samanta et al. (2018) investigated the usefulness of remote sensing, GIS and the frequency ratio (FR) for flood susceptibility mapping. Faisal et al. (2018) analysed the damages caused by flooding according to the different land uses (urban area or agricultural lands), flood height and thus the percentages of loss in the different land uses in various corresponding years in the Naogaon District, Bangladesh using remote sensing and GIS.

Kaduna remains one of the most populated metropolitan urban communities in Northern Nigeria with an estimated population of more than 6 million, according to the 2006 National population census (ZEMDA, 2020). Significant parts of the city have been hit by flood over the years. At present in Nigeria, flood hazard maps are not generally accessible. Until such data is accessible, an assessment of notable flood records or hydrometric information (accessible from the Environmental Protection Agency or Office of Public Works), and/or undertaking flood chance evaluations and examination can demonstrate regions in danger from both stream and tidal flooding. Using AHP, a multi-criteria approach, this study thus sought to identify flood prone areas and produce flood susceptibility map of Makera district in Kaduna South Local Government Area of Kaduna State.

\subsection{Methodology}

\subsection{Description of study area}

The study location covers a land area of about $33.21 \mathrm{~km}^{2}$ which is located in parts of the Makera district in Kaduna South Local Government Area (LGA) of Kaduna state. It has a population of 402,390 according to the 2006 National population census (ZEMDA, 2020). Kaduna South LGA is 
located between latitude $10^{\circ} 25^{\prime} 30^{\prime \prime} \mathrm{N}$ and $10^{\circ} 34^{\prime} 00^{\prime \prime} \mathrm{N}$ of the equator and longitude $7^{\circ} 22^{\prime} 30^{\prime \prime} \mathrm{E}$ and $7^{\circ} 27^{\prime} 30^{\prime \prime} \mathrm{E}$ of the Greenwich Meridian (Ezeamaka et al., 2019). Figure 1 depicts the study area.

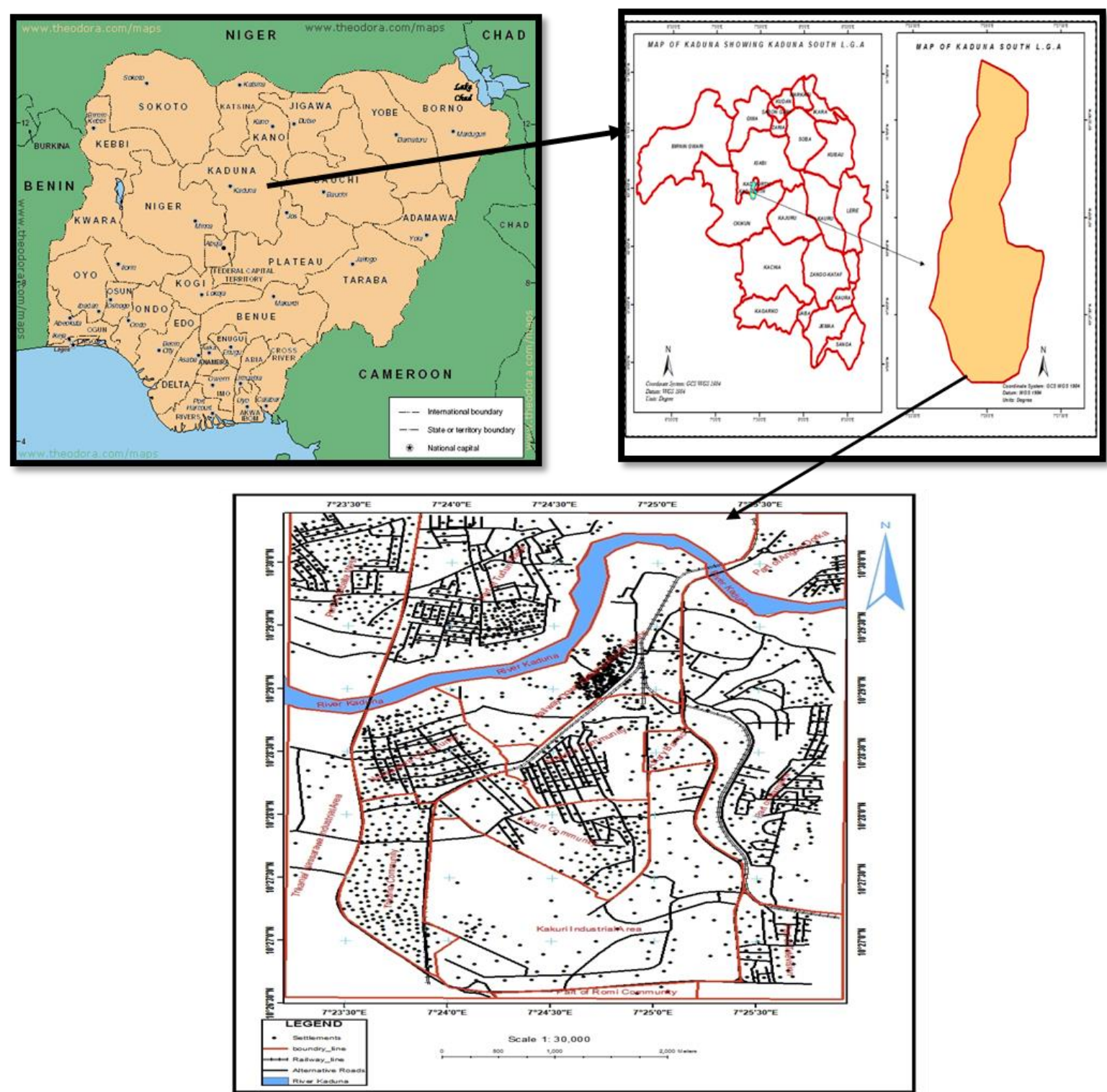

Figure 1: The study area. (Top left: Map of Nigeria; Top right: Maps of Kaduna State Kaduna South LGA; Bottom: Study area)

\subsection{Methods}

The flood susceptibility mapping of any location involves planning the methods to be used as well as the sequential process to adopt for efficiency and quality service delivery. It also involves the sources of data to be utilized and the factors of flooding to be considered and analysed in the production of a flood susceptibility map. The workflow diagram adopted in this study is shown in Figure 2.

\subsection{Data Sources}

Table 1 shows the type of data acquired, resolution, sources, date of acquisition as well as the relevance of the entire primary and secondary data used for this study. 


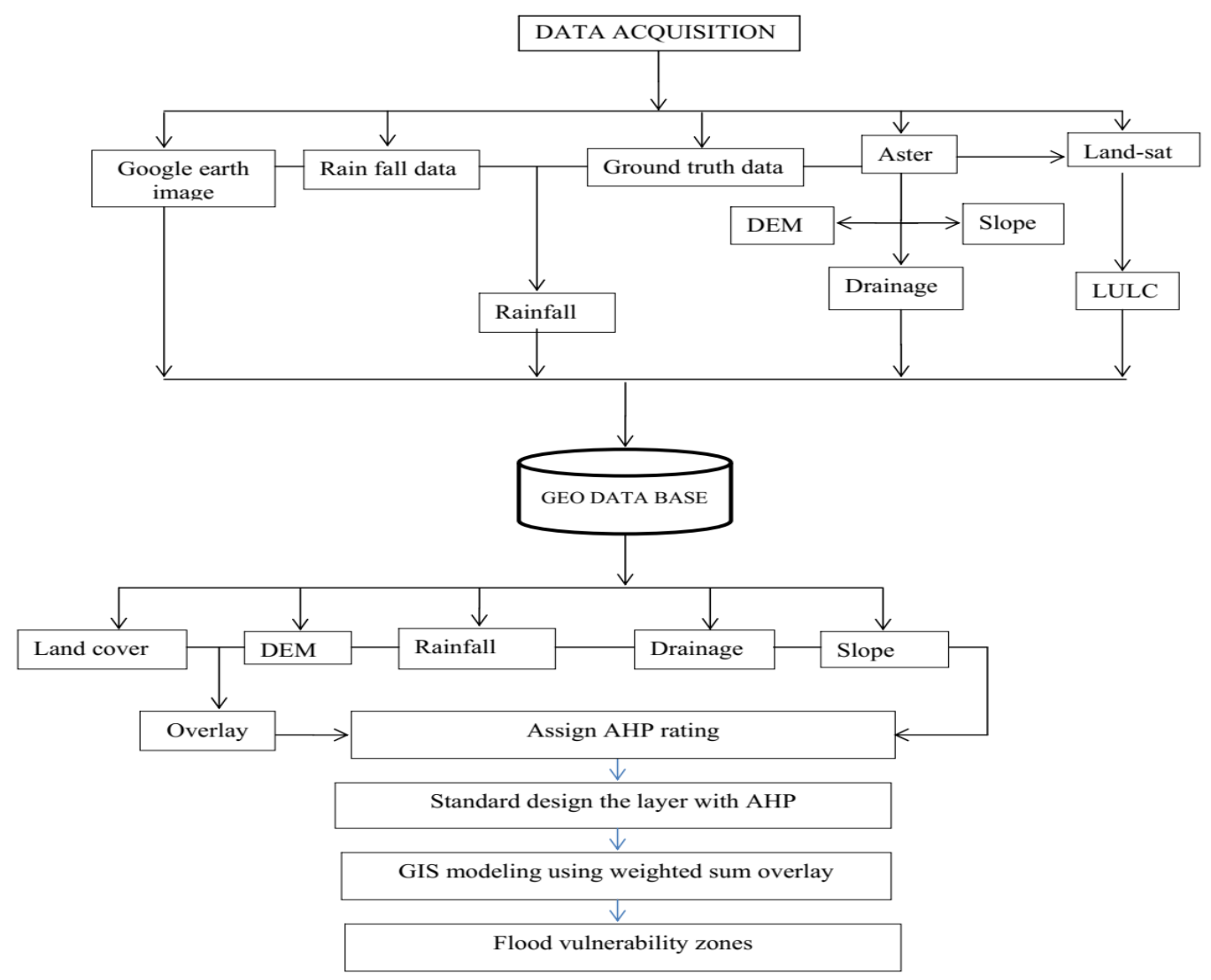

Figure 2: The workflow diagram

Table 1: Datasets and sources

\begin{tabular}{|c|c|c|c|c|}
\hline Data Type & Resolution/Scale & Source & $\begin{array}{l}\text { Date } \\
\text { Acquired }\end{array}$ & Relevance \\
\hline ASTER Data & $30 \mathrm{~m}$ & $\begin{array}{l}\text { United States Geological Survey } \\
\text { (USGS): www.glovis.usgs.gov }\end{array}$ & 2017 & $\begin{array}{l}\text { Generation of } \begin{array}{r}\text { Slope, } \\
\text { Elevation and Drainage } \\
\text { Density layers }\end{array}\end{array}$ \\
\hline Rainfall Data & $\begin{array}{l}36 \text { years } \\
(1981-2017)\end{array}$ & $\begin{array}{l}\text { Nigerian Meteorological Agency } \\
\text { (NiMET) }\end{array}$ & 2017 & Generation of Rainfall layer \\
\hline $\begin{array}{l}\text { Ground Truth } \\
\text { Data }\end{array}$ & 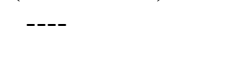 & Field Survey & $\begin{array}{l}\text { December, } \\
2017\end{array}$ & $\begin{array}{l}\text { Determining the boundary of } \\
\text { the communities }\end{array}$ \\
\hline Google Image & $60 \mathrm{~m}$ & Google Earth: www.google.com & 2017 & For processing/digitizing \\
\hline Landsat 8 & $30 \mathrm{~m}$ & $\begin{array}{l}\text { United States Geological Survey } \\
\text { (USGS): www.glovis.usgs.gov }\end{array}$ & 2017 & $\begin{array}{l}\text { Land use land cover } \\
\text { classification }\end{array}$ \\
\hline
\end{tabular}

\subsection{Data processing/preparation}

The data preparation stage included the enhancement of image, transformation of coordinates, vector data trimming of overshoot/overshoots of lines at intersections, closing gaps in lines and generating polygons, associating attribute data with the spatial feature through the manual input method. Since risk zone assessment of floods largely depends on proximity to water body and the terrain of the area, it was therefore necessary to generate the elevation of the area which was achieved through the DEM creation module of the ArcGIS software, using the Digital Elevation Dataset from ASTER DEM, with $30 \mathrm{~m}$ resolution, downloaded from the United States Geological Survey (USGS) (www.glovis.usgs.gov), which automatically showed the topography and the heights of each component of the terrain as well as the proximity to the water body. The drainage flow was integrated into the ArcGIS environment to identify areas most likely to be at the risk of flooding (Youssef and Pradhan, 2011). Daily rainfall data of a rain gauge station that lies around the Kaduna Metropolis was acquired from the Nigeria Metrological Agency (NiMET) Abuja. The mean annual rainfall for 36 years was used to create the rainfall map of the study area by interpolation in the ArcGIS environment. The acquired Landsat8 imagery downloaded from USGS (www.glovis.usgs.gov) was 
ortho-rectified. Using the supervised classification method, the image was classified using spectral signatures (i.e. reflectance values). This was followed by sub-setting, which involved the process of clipping out the area of interest (AOI) otherwise known as the study area from the image. For ground truthing, coordinates of selected features were acquired using the Garmin 78sc Hand held GPS receiver.

\subsection{Deriving criteria weights using analytical hierarchical process (AHP)}

The relationship between five layers and their relationship between their various attributes were derived using the Analytical Hierarchical Process (AHP) (Saaty, 1980) approach. The pair-wise comparison matrix was generated with the relative important values determined from the Saaty's 1-9 Scale (see Table 2) where a score of 1 represents equal importance between two attributes, and a score of 9 indicates the extreme importance between one attribute and another (Saaty, 1980).

Table 2: Fundamental scale for pair-wise comparison (Saaty, 1980)

\begin{tabular}{lll}
\hline Intensity of Importance* & Definition & Explanation \\
\hline 1 & $\begin{array}{l}\text { Equal importance } \\
\text { Moderate importance }\end{array}$ & $\begin{array}{l}\text { Two elements contribute equally to the objective } \\
\text { Experience and judgment slightly favour one } \\
\text { element over another } \\
\text { Experience and judgment strongly favour one } \\
\text { element over another }\end{array}$ \\
7 & Strong importance & $\begin{array}{l}\text { One element is favoured very strongly over another; } \\
\text { Very strong importance }\end{array}$ \\
9 & Extreme importance & $\begin{array}{l}\text { The evidence favouring one element over another is } \\
\text { of the highest possible order of affirmation. }\end{array}$
\end{tabular}

$* 2,4,6$ and 8 are intermediate values

The AHP captures the idea of uncertainty in judgments through the consistency index and the measure of consistency (Saaty, 2000). Consistency Ratio (CR) is a measure of consistency of judgments amongst the criteria.

(a) The rule of thumb states that the CR should be less than or equal to 0.10 ;

(b) Thus a value of 0 to 0.10 is accepted in practice;

(c) Any higher value indicates that the judgment warrants a re-visitation;

(d) CR thus is evaluated as $C R=C I / R I$.

CI which is given by $\frac{\lambda_{\max }-n}{1-n}$, represents consistency index which reflects the consistency of one's judgment. $\mathrm{CI}$ is calculated by averaging the value of the consistency vector (calculated factor weight). RI denotes random inconsistency index that is dependent on the sample size (see Table 3).

Table 3: Random indices (RIs) for $\mathrm{N}=1-10$ (Saaty (1980))

\begin{tabular}{lllllllllll}
\hline $\mathrm{N}$ & 1 & 2 & 3 & 4 & 5 & 6 & 7 & 8 & 9 & 10 \\
\hline $\mathrm{RI}$ & 0 & 0 & 0.58 & 0.89 & 1.12 & 1.24 & 1.32 & 1.41 & 1.45 & 1.49 \\
\hline
\end{tabular}

\subsection{Thematic layer integration}

All the weighed data sets were integrated in the ArcGIS 10.3 software to produce the flood susceptibility map by weighted overlay where each class' individual weight was multiplied by the map scores and the results added. This procedure is facilitated by the following equation (Saaty, 1980):

$$
S=\sum W_{i} X_{i}
$$

where;

$S$-susceptibility

$W_{i}$-weight for each map

$X_{i}$-individual map 


\subsection{Results and Discussion}

The factors contributing to flooding considered in this study include land use and land cover, drainage density, rainfall, elevation and slope, respectively.

\subsection{Land use}

Land use affects the surface runoff, evapo-transpiration and rate of infiltration (Yalcin et al., 2011). For the land use classification based on the supervised method, five different classes were considered which include vegetation, built-up, farmland, water body and bare ground (see Figure 3). The land use and land cover classification shows that farmland areas account for $40.11 \%$ of the total land coverage while built-up, vegetation, bare ground and water body account for $29.34 \%, 20.72 \%, 5.05 \%$ and $4.77 \%$, respectively. Table 4 summarizes the land use and land cover class of the study area and the corresponding percentage of each feature.

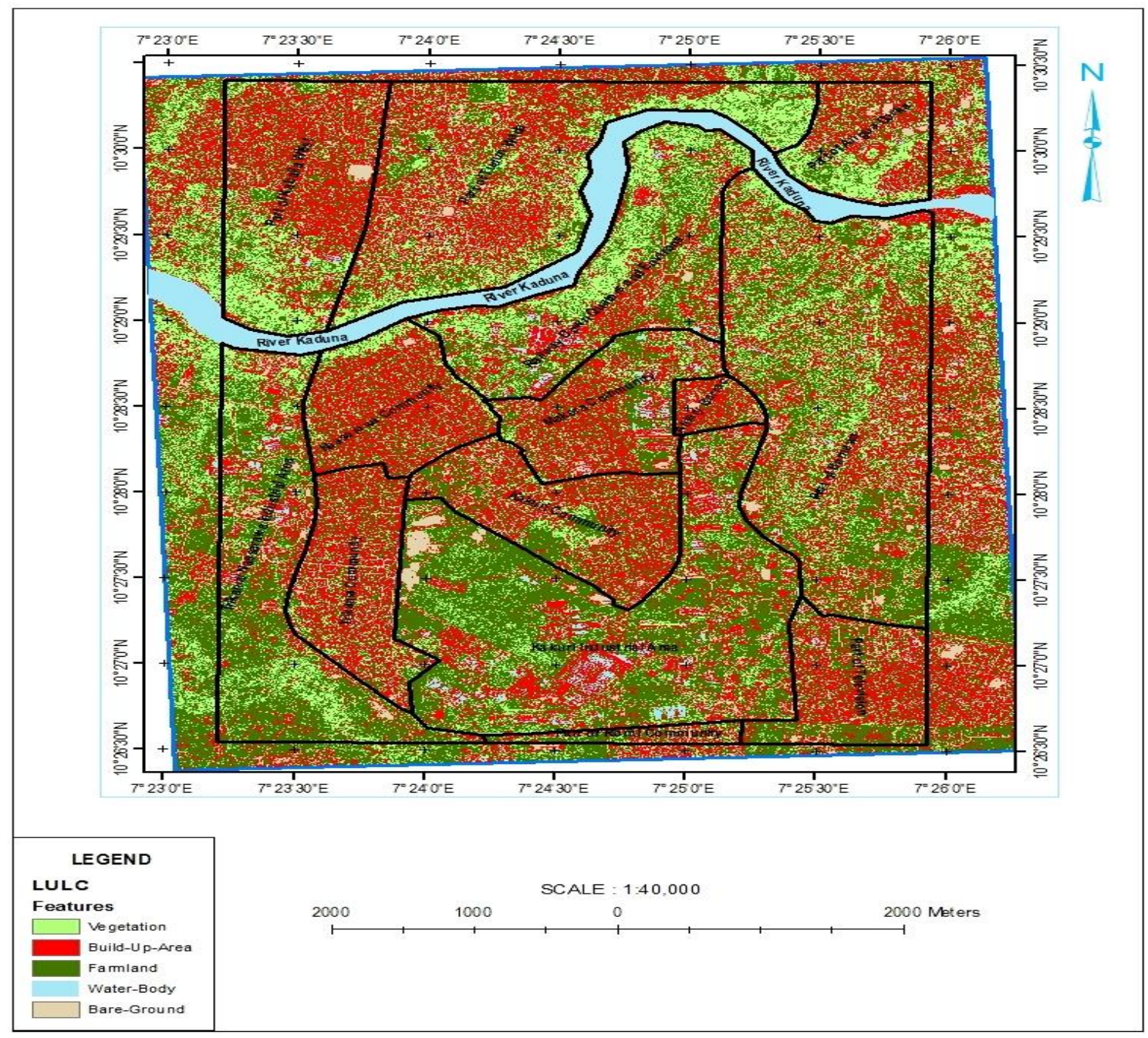

Figure 3: LULC map of the study area.

Table 4: Land use and land cover classes

\begin{tabular}{lll}
\hline LULC Feature & Area (ha) & Percentage $(\%)$ \\
\hline Vegetation & 662.87 & 20.72 \\
Built-up & 938.48 & 29.34 \\
Farmland & 1282.93 & 40.11 \\
Water body & 152.63 & 4.77 \\
Bare ground & 161.68 & 5.05 \\
\hline Total & 3198.59 & 100.00 \\
\hline
\end{tabular}




\subsection{Land use drainage density}

The drainage density of any given area shows how well or poorly a watershed is drained by stream channels. Drainage density has been recognized as significant factor on the formation of flood flows (Gardiner and Gregory, 1982). Thus a high density indicates a greater flood risk, while a low density generally implies decreasing flood volume. The drainage density (see Figure 4) was generated from the DEM. The drainage density was divided into five catchment (0 to $28400 \mathrm{~km})$ areas. Scott et al. (2015) observed that the topography of a drainage basin can affect the speed with which the precipitation flows. In other words, the steeper the basin, the more quickly it drains and vice versa.

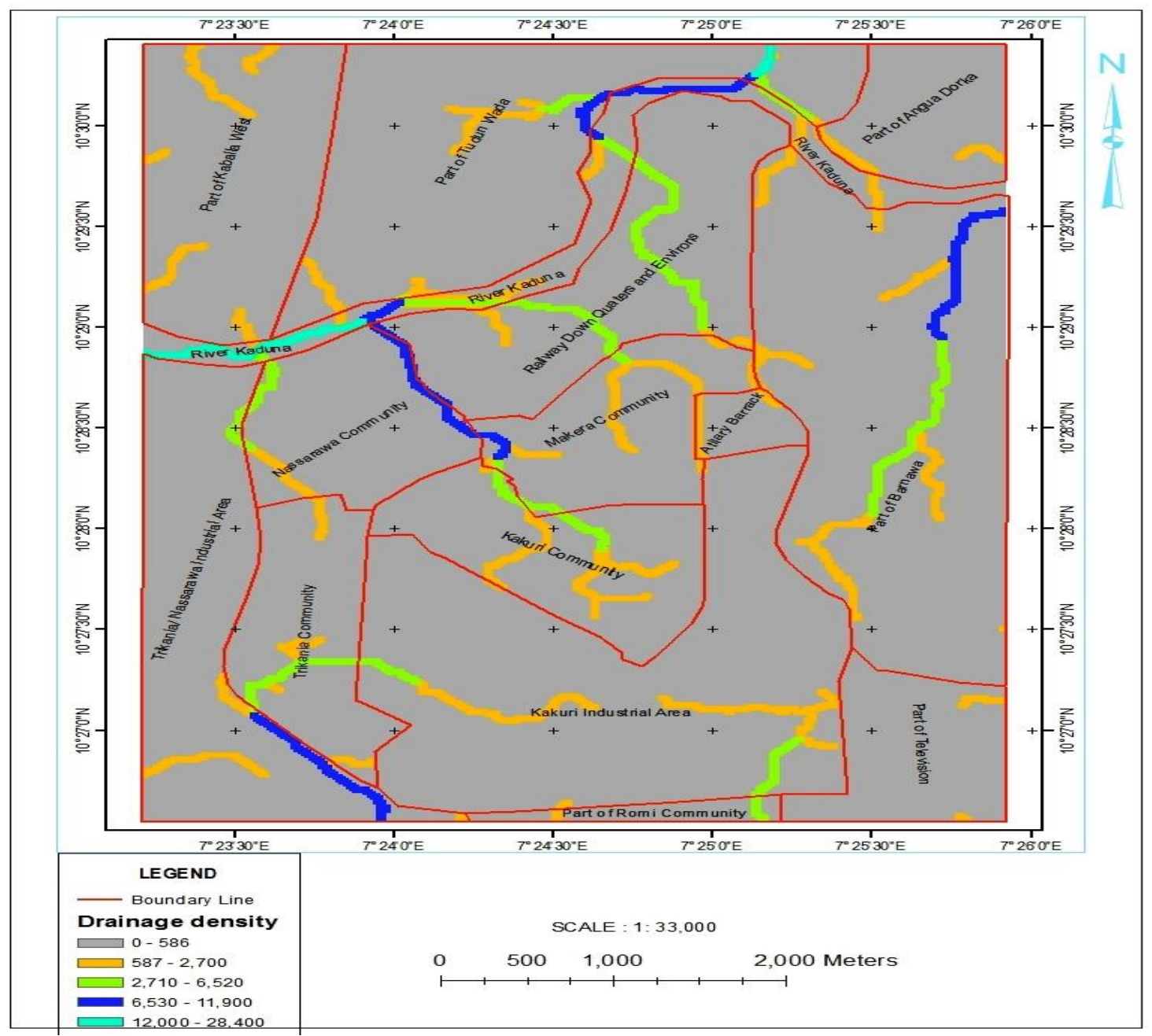

Figure 4: Drainage density based on catchment area

\subsection{Rainfall}

The rainfall pattern of the study area was generated from the rainfall data obtained from the Nigeria Metrological agency (NiMET) Abuja. The rainfall data (10 stations) for a period of 36 years (19812017) was collected and interpolated in the spatial analysis tool of the ArcGIS 10.3 software. The results revealed that the rainfall amount in the study area ranged from $1290 \mathrm{~mm}$ to $1178 \mathrm{~mm}$ per annum (see Figure 5). Higher rainfall amount might probably mean grater flood risk. 


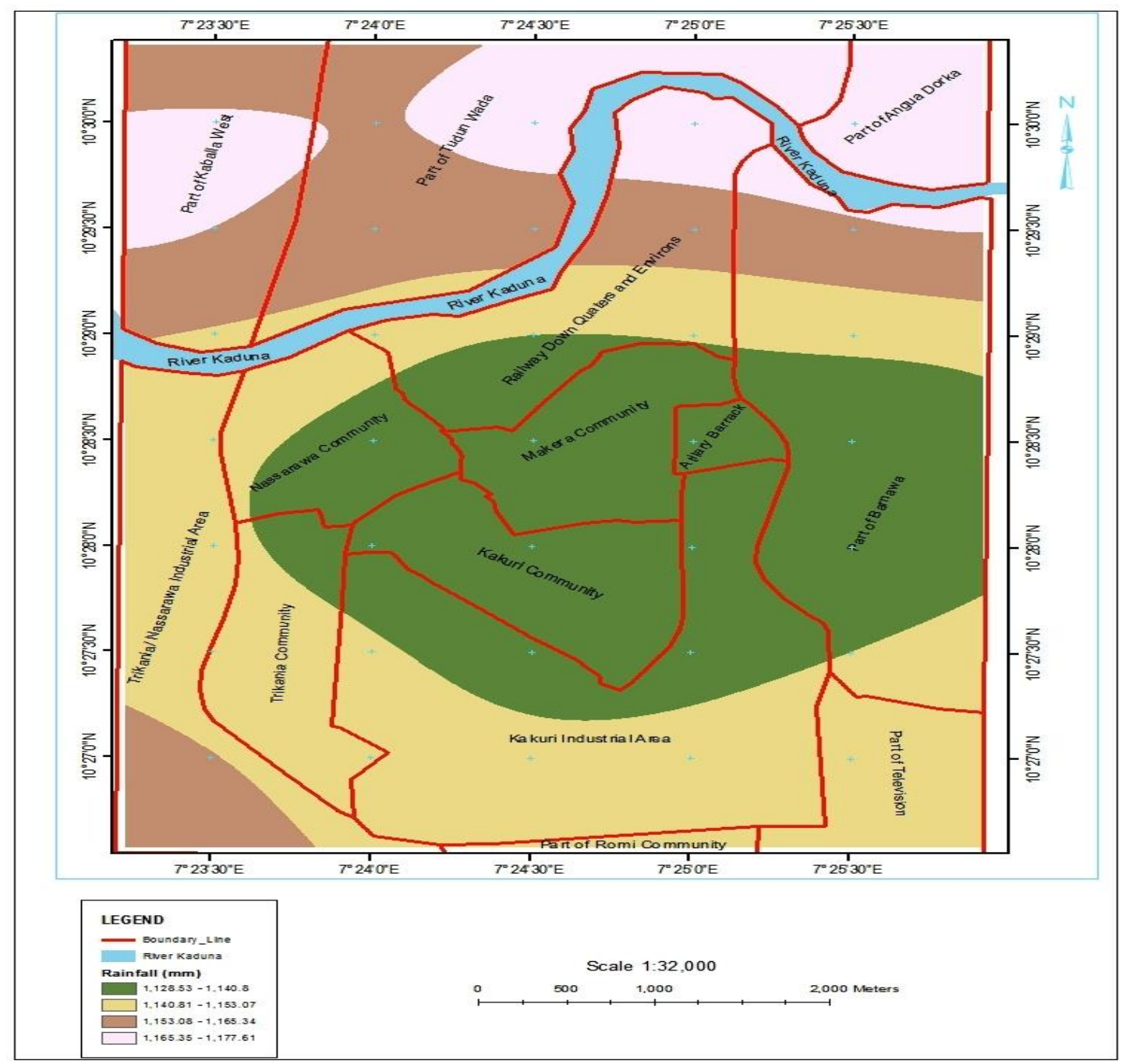

Figure 5: Rainfall pattern of the study area

\subsection{Elevation and slope}

The elevation dataset was obtained from the ASTER DEM which reveals that the elevation of the study area ranges from $542.20 \mathrm{~m}$ to $634.70 \mathrm{~m}$ (see Figure 6). Figure 7 presents the slope map for the study area. The result obtained shows that the slope of the study area ranges from 0.003 to 25.40 degrees. 


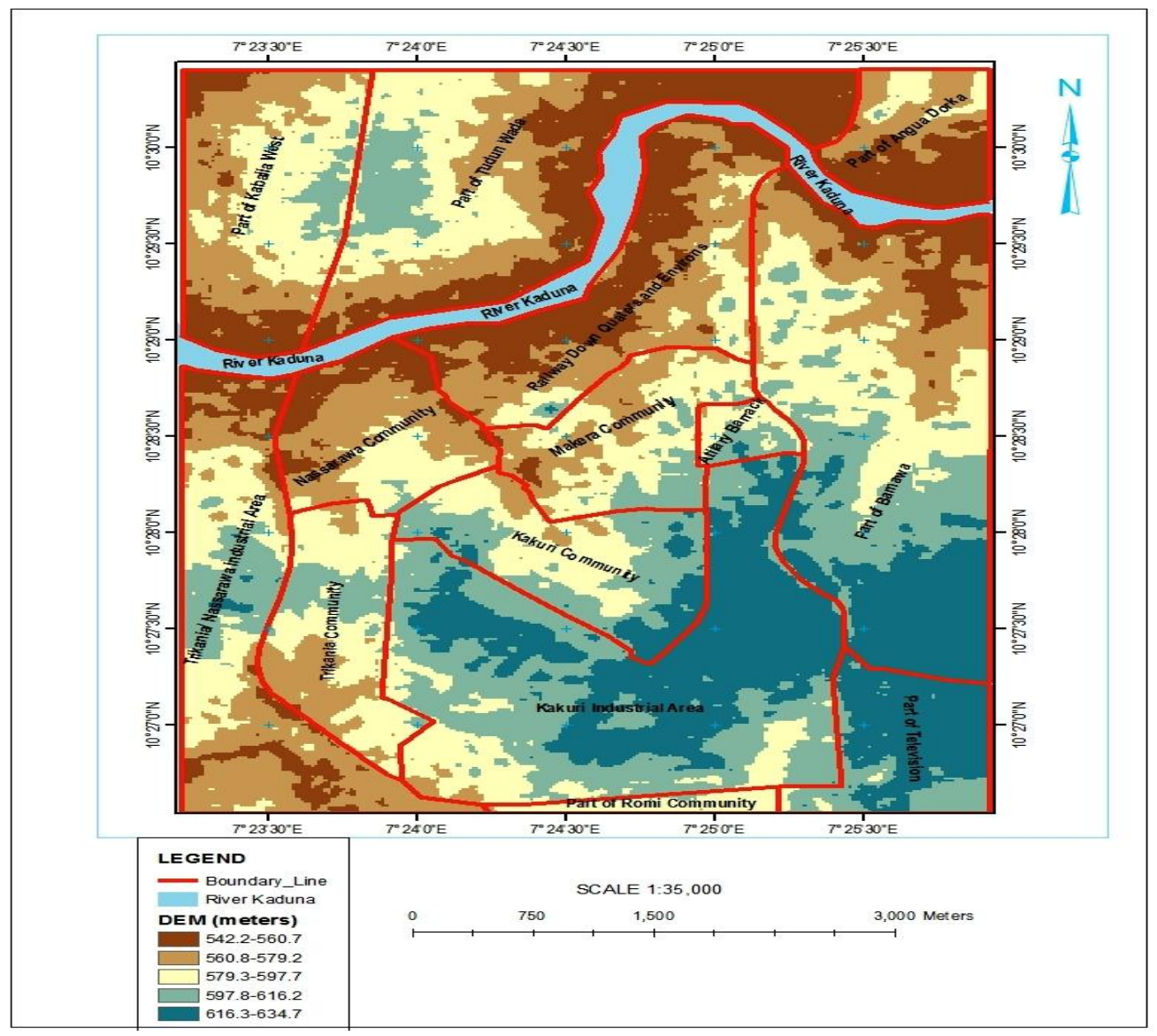

Figure 6: Elevation pattern of the study area

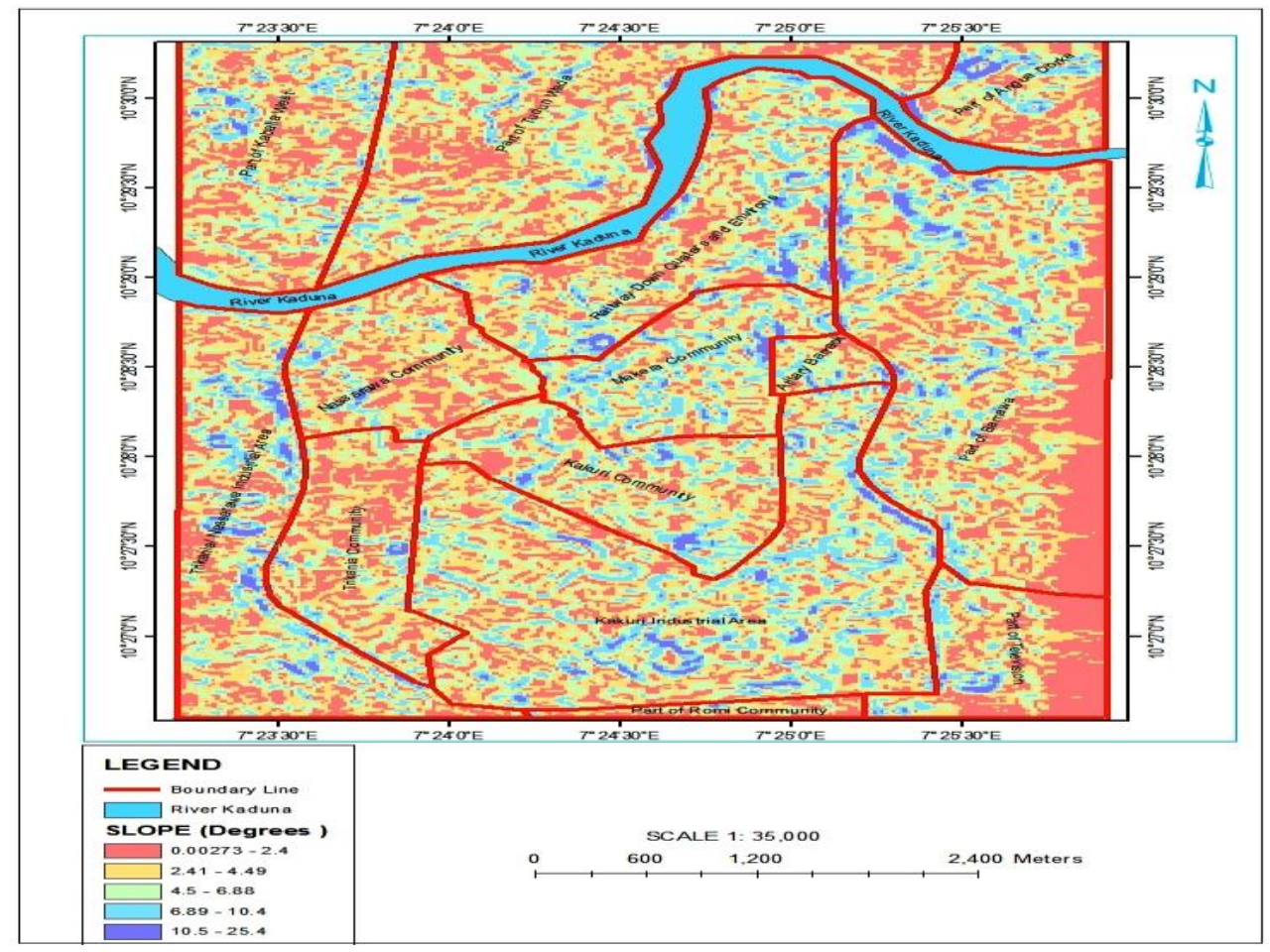

Figure 7: Slope pap of the study area

\subsection{Flood susceptibility map}

This section presents the result of the pair-wise comparison carried out for the five factors contributing to flooding under consideration in this study and the generated flood susceptibility map. 
Table 5 presents the pair-wise comparison matrix for the factors contributing to flooding in the study area.

Table 5: Pair-wise comparison matrix for factors of flooding

\begin{tabular}{lllllll}
\hline Features & Rainfall & DEM & Slope & Drainage & LULC & Weight \\
\hline Rainfall & 1 & $1 / 4$ & $1 / 5$ & $1 / 7$ & $1 / 9$ & 0.47 \\
DEM & 4 & 1 & 5 & $1 / 3$ & $1 / 6$ & 0.14 \\
Slope & 5 & $1 / 4$ & 1 & $1 / 4$ & $1 / 7$ & 0.09 \\
Drainage & 7 & 3 & 4 & 1 & $1 / 2$ & 0.33 \\
LULC & 9 & 6 & 7 & 2 & 1 & 0.60 \\
\hline \multicolumn{7}{c}{ Consistency Ratio $(C R)=0.06$} \\
\end{tabular}

From the results of the various weights generated it has been revealed that the land use and land cover factor with 0.60 as its weight has the greatest influence on flood occurrence in the study area. This is followed by Rainfall (0.47), Drainage Density (0.33), Elevation (0.14), and Slope (0.09), respectively. The CR value of 0.06 indicates that the weighting of the factors was consistent (i.e. CR < 0.1 ). Table 6 shows the percentage of the various areas covered by the flood.

Table 6: Area coverage of the flood susceptibility zones

\begin{tabular}{lll}
\hline Susceptibility & Area (ha) & Percentage (\%) \\
\hline Very High & 423.50 & 14.90 \\
High & 682.09 & 24.10 \\
Moderate & 736.10 & 25.90 \\
Low & 588.90 & 20.71 \\
Very Low & 411.71 & 14.49 \\
\hline Total & 2842.29 & \\
\hline
\end{tabular}

From the flood susceptibility map (see Figure 8), it shows that about 423.50 ha which is about $14.90 \%$ of the study area is very highly vulnerable to flood, and these areas include large parts of railway down quarter, Anguwan Dorka, parts of Nassarawa, Kaballa west and Tudunwada. Areas with high flood susceptibility include the southern parts of Trikania, Nassarawa, and some parts of Barnawa covering 682.09 ha which is about $24.10 \%$ of the study area. Moderate venerable areas covered large parts of Tudunn Wada, part of Kaballa west, large part of Barnawa, Kakuri community, part of Makera and Romi covering 736.10 ha which is about $25.90 \%$ of the total project area. Areas with low susceptibility are some parts of Kakuri, Television, and Barnawa covering 588.90 ha which is about $20.71 \%$ of the total area. The areas that are not vulnerable are large parts of Kakuri industrial area, Television, and a little part of Barnawa representing 411.71 ha which is about $14.49 \%$ of the study area.

\subsection{Discussions}

The primary purpose of flood mapping is to delineate zones with high susceptibility. Flood modelling approach differs considerably, hence enabling different predictive performance and outputs (Nachappa et al., 2020). Das (2020) adopted more than eleven factors (elevation, slope, distance from drainage, drainage density, flow accumulation, topographic wetness index, rainfall, land use, soil texture, topographic ruggedness index and geology, including socio-economic factors) to map flood prone areas in the Western Ghat coastal belt of India. For convenience and data limitation, and based on Ozkan and Tarhan (2016), the present study, adopted only five factors to construct a flood susceptibility map of Makera district and environs in Kaduna South local government area of Kaduna state-Nigeria using AHP. 


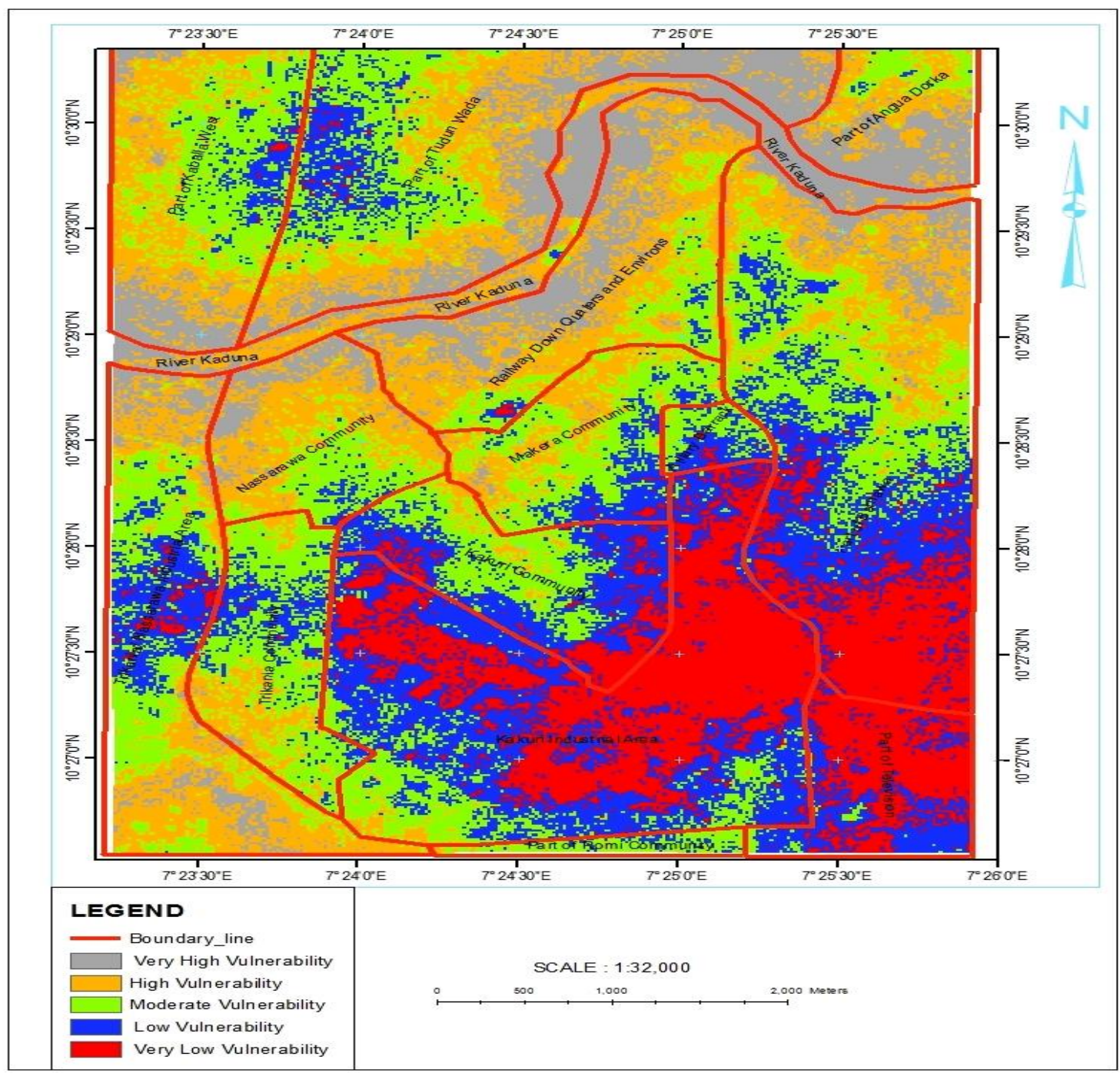

Figure 8: Flood susceptibility map of the study area

The study revealed that the element at risk in the study area shows that farmland accounted for 1282.93 ha $(40.11 \%)$ which was the major element at risk in the study area followed by built-up area which was about 938.84ha (29.34\%) and vegetation accounted for 662.873ha (20.72\%). By taking the average of very high and high percentage (see Table 6) of the vulnerable zones, we can conclude that about $19.5 \%$ of the study area show high flood risk. The study area is quite populated as a result of urban migration from urban to rural areas in search of greener pastures. Immigrants tend to violate urban building laws and encroach into green areas. Similarly, there are numerous poor drainage system is another factor. Though, the results of this study do not corroborate any study of its kind in the region due to the unavailability of similar studies in the region. It is expected that results can be improved if more risk factors are considered (see for example: Nachappa et al., 2020; Das, 2020). Similarly, the accuracy of the result is also affected by the accuracy and sampling error of the DEM (Ozkan and Tarhan, 2016).

\subsection{Conclusions}

The study assessed the flood vulnerable areas in the Makera district and environs in the Kaduna South Local Government Area of Kaduna State by adopting geospatial techniques and the multi-criteria analysis approach. The study showed that farmlands are most vulnerable to floods in the study area followed by built-up area, and vegetation, respectively. The study also revealed that land use and land cover was the most contributing factor to flood in the study area followed by Rainfall, Drainage Density, Elevation, and Slope, respectively. Thus it can be concluded from this study that although flood is a natural disaster, the activities of man contribute immensely to flood occurrence. These activities include encroachment, violation of building laws, and poor drainage system among others. 
The authorities and local community leaders can encourage the improvement of flood hazard information, data collection and prediction capabilities. Land use planning that prevents development on floodplains and allows the areas to be reserved for agricultural or recreational purposes should be improved upon.

For decision support system, numerous studies have utilised slope, LULC, soil type, elevation, rainfall etc. Nevertheless, soil type is one of the most important factors in defining an area's water retention and absorption properties, which influences flood susceptibility. However, due to the unavailability of soil type with acceptable spatial resolution in the study area, the study failed to use soil type as a factor. Not until recently, Nkwunonwo et al. (2020) proposed a soil map for Nigeria from 1985 reconnaissance soil survey. Overtime, due to anthropogenic and non- anthropogenic activities a soil survey of 1985 and completed in 1990 must have change in properties and characteristics. This soil type data to the conception of the current study are biased. On a final note, the study recommends that future studies uses soil type of high spatial and temporal resolution. This can be done by fusion of International Soil Reference and Information Centre (ISRIC) data (https://data.isric.org/geonetwork/) and that of Nkwunonwo et al. (2020).

\section{References}

Das, S. (2020). Flood susceptibility mapping of the Western Ghat coastal belt using multi-source geospatial data and analytical hierarchy process (AHP). Remote Sensing Applications: Society and Environment. https://doi.org/10.1016/j.rsase.2020.10037

Ezeamaka, C., Daful, M. and Umeano, E. (2019). Land-use and Land-cover Analysis of Kaduna South Local Government Area, Kaduna State, Nigeria. American Journal of Environmental Protection, 8, pp. 62-71. doi.10.11648/j.ajep.20190803.11

Faisal, A., Kafy, A. and Roy, S. (2018). Integration of Remote Sensing and GIS Techniques for Flood Monitoring and Damage Assessment: A Case Study of Naogaon District, Bangladesh. Journal of Remote Sensing and GIS, 7(2). doi: 10.4172/2469-4134.1000236

Gardiner, V. and Gregory, K. J. (1982). Drainage Density in Rainfall Runoff Modelling, In: V. P. Singh (Ed), Rainfall Runoff Relationships, (pp. 449-476). Littleton, Colorado: Water Resource Publications.

Haq, M., Akhtar, M., Muhammad, S., Paras, S. and Rahmatullah, J. (2012). Techniques of Remote Sensing and GIS for Flood Monitoring and Damage Assessment: A Case Study of Sindh Province, Pakistan. The Egyptian Journal of Remote Sensing and Space Sciences, 15(2), pp. 135-141. http://dx.doi.org/10.1016/j.ejrs.2012.07.002

Ikusemoran, M. (2000). Remote Sensing and GIS for Flood Surveillance: A Case Study of Kainji Lake Basin, New Bussa, Nigeria. M. Tech. Thesis, Department of Geography, Federal University of Technology, Minna. Unpublished.

Nachappa, T. G., Piralilou, S. T., Gholamnia, K., Ghorbanzadeh, O., Rahmati, O. and Blaschke T. (2020). Flood susceptibility mapping with machine learning, multi-criteria decision analysis and ensemble using Dempster Shafer Theory. Journal of Hydrology, 590, p.125275. https://doi.org/10.1016/j.jhydrol.2020.125275

Nkeki, F. N., Henah, P. J. and Ojeh, V. N. (2013). Geospatial Techniques for the Assessment and Analysis of Flood Risk along the Niger-Benue Basin in Nigeria. Journal of Geographic Information System, 5, pp. 123-135.

Nkwunonwo, U. C., Okeke, F. I., Ebinne, E. S., and Chiemelu, N. E. (2020). Free, open, quantitative and adaptable digital soil map data and database for Nigeria. Data in Brief, 31, 105941. https://doi.org/10.1016/j.dib.2020.105941 
Nwilo, P. C., Olayinka, N. D. and Adzander, A D. (2012). Flood Modelling and Susceptibility Assessment of Settlements in the Floodplains Using GIS and Cellular Framework Approach. Global Journal of Human Social Sciences, 12(3), pp. 11-20.

Ojeh, V. N. and Victor-Orivoh, A. F. (2014). Natural Hazard and Crop Yield in Oleh, South-South Nigeria: Flooding in Perspective. Journal of Earth Science and Climatic Change, 5, 181. http://dx.doi.org/10.4172/2157-7617.1000181

Okonkwo, I. (2013). Effective Flood Plain Management in Nigeria: Issues, Benefits and Challenges. Transparency for Nigeria, http://transparencyng.com

Oxford Learner's Dictionary (2020). Flood. Retrieved March 4, 2020, from https://www.oxfordlearnersdictionaries.com/definition/english/flood_1

Ozkan, S. P., and Tarhan, C. (2016). Detection of flood in urban areas using GIS: Izmir case. $9^{\text {th }}$ international conference interdisciplinary in engineering inter-eng 2015 8-9 October 2015 TirguMures Romania. Procedia Technology, 22, pp. 373-381. doi: 10.1016/j.protcy.2016.01.026

Pieter, D., Wim, K., Johan, R., Wouter, V. and Philippe, D. M. (2010). Geospatial Techniques in Urban Hazard and Disaster Analysis. Geotechnologies and Environment, pp. 51-69.

Saaty, T. L. (1980). The Analytical Hierarchical Process. New York: McGraw-Hill.

Saaty, T. L. and Vergas, L. G. (2000). Models, Methods, Concepts and Application of the Analytical Hierarchical Process.

Samanta, S., Pal, D. K. and Palsamanta, B. (2018). Flood Susceptibility Analysis through Remote Sensing, GIS and Frequency Ratio Model. Applied Water Science, 8 (2), pp. 1-14. https://doi.org/10.1007/s13201-018-0710-1

Scott, H., Fiona, F., David, W., Paul, B., Cherie, C. and Braeden, L. (2015). The Living Murray Condition Monitoring at Lindsay, Mulcra and Wallpolla Islands 2015-16 Part A-Main Report.

Vallecillo, S., Kakoulaki, G., La-Notte, G., Feyen, F., Dottori, F., and Maes, J. (2020). Accounting for changes in flood control delivered by ecosystems at the EU level, Ecosystem Services 44, p.101142. https://doi.org/10.1016/j.ecoser.2020.101142

Yalcin, A., Reis, S., Cagdasoglu, A. and Yomralioglu, T. (2011). A GIS-based comparative study of frequency ratio, analytical hierarchical process, bivariate statistics and logistic regression methods for landslide susceptibility mapping in Trabzon, NE Turkey. Catena, 85, pp. 274-287.

Youssef, A. M. and Pradhan, B. (2011). Flash Flood Risk Estimation along the St. Katherine Road, Southern Sinai, Egypt using GIS Based Morphometry and Satellite imagery. Environ. Earth Sci, 62 (3), pp. 611-623.

ZEMDA (2020). Population of Kaduna South Local Government Area, Kaduna State-Nigeria. Retrieved at: https://zemda.org.ng/wp/local-goverments/kaduna-south/. Accessed on $25^{\text {th }}$ February, 2020.

\section{Cite this article as:}

Ibrahim U. S., Youngu T. T., Swafiyudeen B., Abubakar A. Z., Zainabu A. K., Usman I. A., Adamu S., and Abubakar A. M., 2021. Flood Susceptibility Mapping of Makera District and Environs in Kaduna South Local Government Area of Kaduna State-Nigeria. Nigerian Journal of Environmental Sciences and Technology, 5(2), pp. 420-432. https://doi.org/10.36263/nijest.2021.02.0287 